\title{
Optimization of Green Building for Low-income People at Pondicherry
}

\author{
M. N. Uddin ${ }^{1, *}$, A. Muthu Selvam ${ }^{2}$, J. Shahoonda ${ }^{2}$, R. Prasanth ${ }^{2}$ \\ ${ }^{1}$ Department of Building and Real Estate, the Hong Kong Polytechnic University, Hung Hom, Hong Kong, China \\ ${ }^{2}$ Centre for Green Energy Technology, Pondicherry University, Puducherry, India
}

Copyright $\odot 2018$ by authors, all rights reserved. Authors agree that this article remains permanently open access under the terms of the Creative Commons Attribution License 4.0 International License

\begin{abstract}
Green building is the way of creating structures and using processes that are environmentally responsible and resource-efficient throughout a building's life-cycle from construction, operation, maintenance, renovation, and deconstruction. This practice enlarges and complements the conventional building design concerns of energy, water, materials, carbon emission, economy, utility, durability, and comfort. Hence, these practices have the sole role in sustainable as well as high-performance building. Outdated methods of building or renovation a home uses a huge amount of resources which contain a significant amount of carbon emission and many of them nonrenewable and toxic - and pay little attention to the impact the home's site have on the landscape. Herein, we elucidate a green building optimization for low-income people with the help of Autodesk Revit as well as EDGE green building analyzer. We designed a sustainable building model by using these tools based on energy efficiency, water efficiency, locally available and low carbon content materials, generate less waste and afford improved spaces for inhabitants, as compared to a traditional building. Embodied energy analysis, material flow analysis, carbon emission analysis and cost optimization are carried out to produce an optimum result.
\end{abstract}

Keywords Green Building, Pondicherry, Optimization, EDGE, Materials Efficiency, Energy Efficiency, Water Efficiency \& Cost

\section{Introduction}

A green building is an outcome of a design philosophy which focuses on increasing the efficiency of resource use; energy, water, and materials through minimizing the influence on health and environment through the building's lifecycle, concluded better construction, design, operation, maintenance, and removal. There are various sustainability concepts for green building optimization such as site selection, orientation, materials selection, energy efficient appliances, heating, cooling etc. [1].

Buildings cannot escape their responsibility in contributing to this environmental deterioration. Construction contributes to the loss of agricultural land and forests, to air pollution and the industry is a major user of the world's non-renewable energy sources and minerals (Spence and Mulligan, 1995). The US Green Building Council (USGBC, 2009) data shows that buildings in the United States consume 30 percent of the world's total energy and account for 48 percent of greenhouse gas (GHG) emissions in the US [2].

Now- a -day the popularity of green building is increasing day by day. With the increasing demand for green buildings, the construction industry is faced with the challenge to ensure that the building performance predicted during the design is achieved once a building is in use $[1,3]$. Even though green buildings have the potential to offer win-win scenarios and that green buildings are currently constructed in different countries, although the adoption of green buildings does have some obstructions [4].

The construction industry is the second largest industry in India which provides employment for a huge number of people and makes a major contribution to the national economy after agriculture. In a country like India where the population is ever increasing, so are the demands. The demand for houses, shopping malls, hotels, commercial complexes etc. are on the rise. An emerging alternative is to go green in housing too. Indian Green Building Council (IGBC, 2014) promotes and regulates all activities connected with green buildings and greenhouses in India. However, the role of marginalized and low-income people in creating and protecting a green environment is not investigated properly. Most of these people are living still in hamlet under unhygienic surroundings. Developing green building concepts for rehabilitating these people has long-term economic values [5].

Pondicherry is the capital city of The Union Territory (UT) of Puducherry and is one of the most popular tourist destinations in South India. The UT of Puducherry shares a 
state border and cultural and linguistic similarities with Tamil Nadu. It comprises of 4 coastal regions namely Pondicherry (294 sq.km), Karaikal (157 sq.km), Mahe (9 sq.km) and Yanam (30 sq.km) [6]. About $45 \%$ of the total population earns their livelihood from agriculture and other related activities. Industrial development in the region has been slow. Some of the important businesses are light engineering, metals, tourism, chemicals, textiles, food processing etc. [7]. The Government Square is the only major green space in Pondicherry within the boulevards, surrounded by public buildings. More than $90 \%$ of the people follow the traditional methods for their house construction and they are not realized about the importance of green building construction. In the present study, the effective use of locally available materials has been carried for constructing houses for the low-income family with four members and discuss how energy efficiency, emission reduction can be optimized for the building [7].

\section{Site and Materials Study at Pondicherry}

The availability of affordable eco-friendly materials in Pondicherry. Auroville Earth Institute (AEI) is the major source of green construction materials in Pondicherry [8]. AEI does research into \& promotes earth-based technologies, including compressed stabilized earth blocks (CSEBs); the main $\mathrm{R} \& \mathrm{D}$ is focused on minimizing the use of steel, cement \& reinforced cement concrete (RCC) offers training, courses etc. which aim to introduce and promote the technology of stabilized earth to build with sustainable environment. Such products promote resource conservation and efficiency. Choose materials that have low environmental costs and do not contribute to indoor air pollution [9].

\section{Flooring \& Foundation}

A planned foundation can variety a considerable influence on controlling heat and cooling charges though removing possible moisture and mold difficulties. There are several types of foundations to choose from, dependent on soils condition, water table, climate etc. Crushed rock stone [Fig.1] is one of the utmost available natural resources and it is a major basic raw material used by flooring \& foundation construction at Pondicherry which is mixed with fly ash aggregates, stones etc.

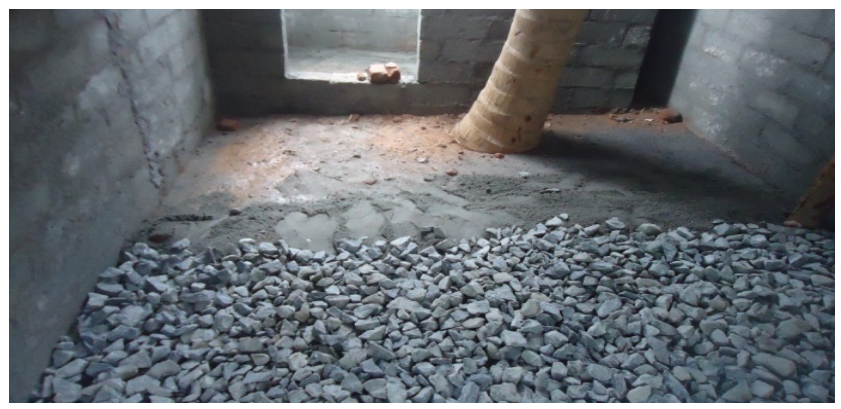

Figure 1. Rock stone
Terracotta [Fig.2] the floor is known for its durability and earthy appeal. Terracotta, literally 'cooked earth,' is a ceramic that is manufactured by firing refined clay mixtures at high temperatures in kilns [10]. When properly installed and maintained its more durable. This reduces time, money and resources spent on extracting raw material, manufacturing, transportation, installation, demolition, and disposal requirement.

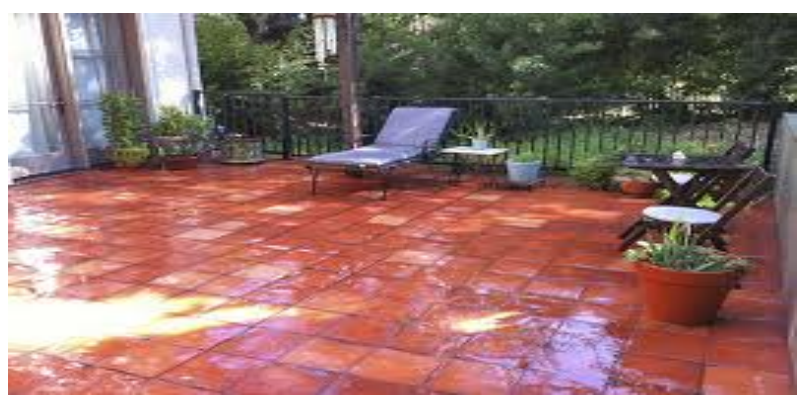

Figure 2. Terracotta floor (Source: Google)

\section{Wall Construction}

The main purpose of using alternate and locally available materials is to minimize the negative effects that our built environment can have on the planet while increasing the efficiency and adaptability of the structures. Fly ash bricks is the best suited for constructing materials which are eco-friendly also locally available [11]. This type of bricks specifically masonry units, containing class C fly ash and water. This brick (cement bonded) shall be locally made. It has smooth rectangular faces with square and sharp corners. Moreover, people of Pondicherry mostly used conventional bricks for their house construction which is shown in Fig.3.
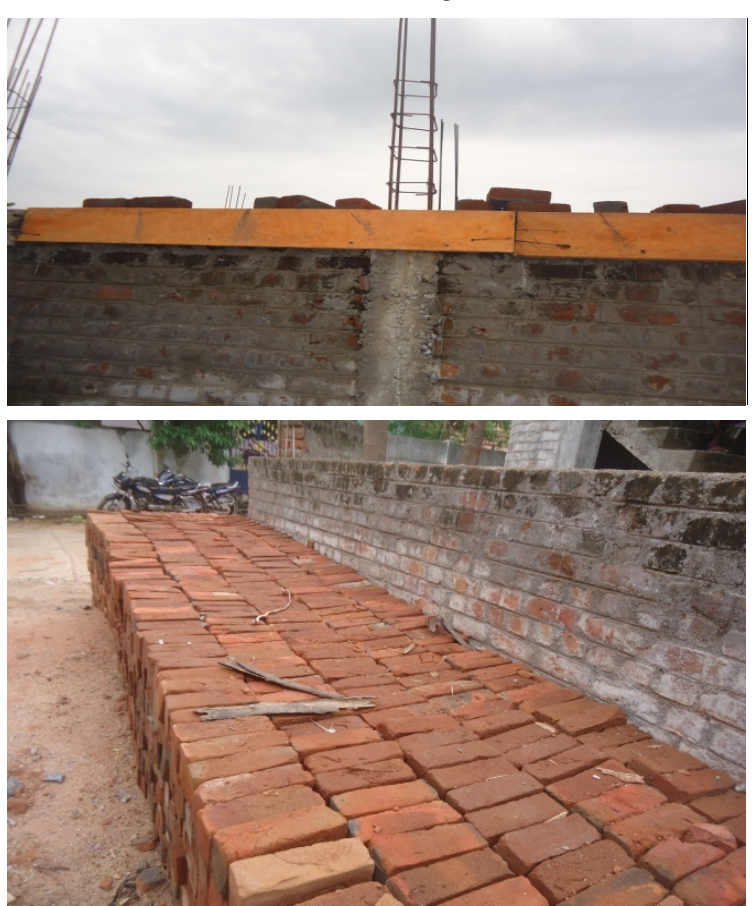

Figure 3. Conventional bricks (Kalapet-Pondicherry) 
Coconut and bamboo timbers [Fig.4] have many applications as a structural building material, particularly for housing in rural coconut growing areas like Puducherry. This wood has been successfully used to build houses of different standards for industrial and office construction as well as buildings at Puducherry region.
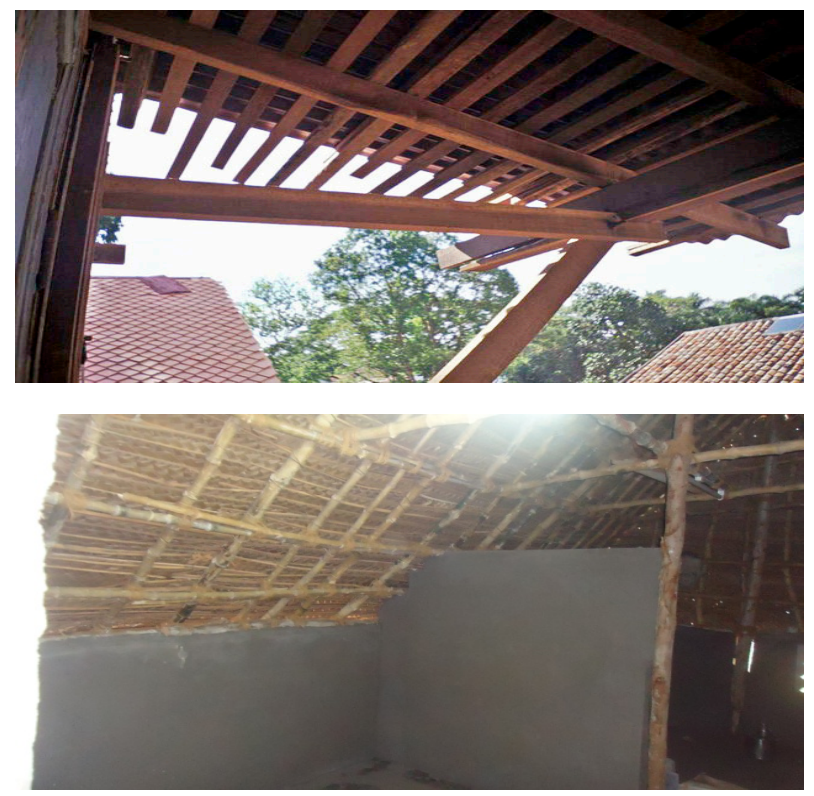

Figure 4. Roof beam constructed by coconut wood and bamboo (Source: https://archnet.org)

\section{Roofing Materials}

Plywood [Fig.5 (a)] is a versatile building material that can be used in decks, flooring, roofing, and walls. It is used in various interior and exterior applications and found in boat construction. It is a durable material that provides an excellent foundation for a building. The frequently used thickness varies from 0.14 to 3.0 inches. The dimensions of the most regularly used plywood sheets are 4 by 8 feet. Width and length may vary in 1-foot increments [12].

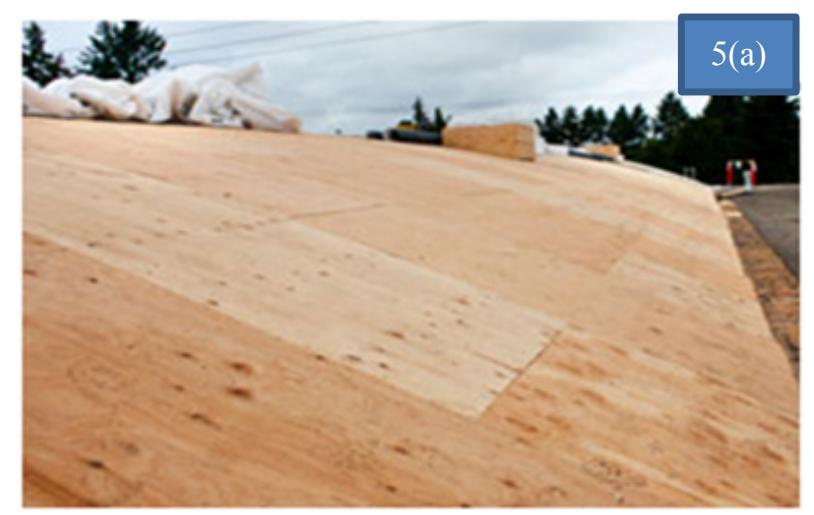

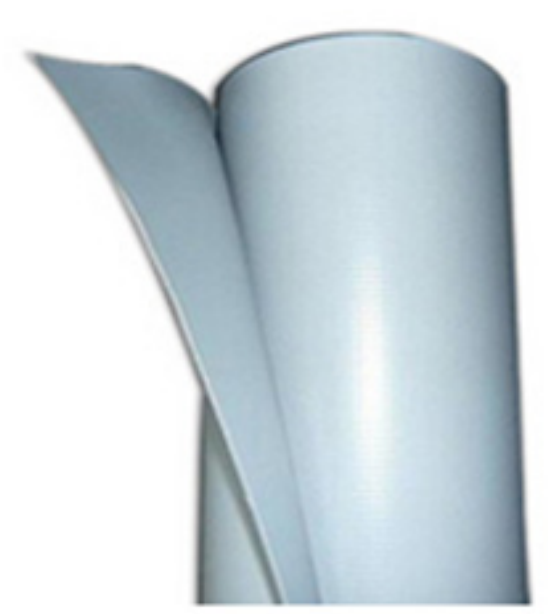

Figure 5. (a) Roof constructed by plywood (b) Poly-flex membrane (Source: Google)

Poly-flex [Fig.5 (b)] is intended to be used as a base sheet or inter-ply in new or re-roof applications. Poly-flex may be applied directly to non-combustible substrates. Poly-flex requires the installation of a compatible granulated cap sheet to complete the roofing system. Smaller to bigger buildings are used as shopping malls, industries, factories, and residences. Thermal and environmental properties of poly-flex are shown in Table-1.

Table 1. Thermal \& Environmental property of poly-flex [13]

\begin{tabular}{|c|c|}
\hline Properties/Particulars & Values /Comments \\
\hline Glass transition temperature & $-54^{\circ} \mathrm{C}$ \\
\hline $\begin{array}{c}\text { The coefficient of thermal } \\
\text { expansion linear }\end{array}$ & $160 \mu \mathrm{m} / \mathrm{m} \cdot \mathrm{K}$ \\
\hline Maximum service temperature & $150{ }^{\circ} \mathrm{C}$ \\
\hline Minimum service temperature & $-50^{\circ} \mathrm{C}$ \\
\hline Ozone Resistance & Good to Excellent \\
\hline Radiation Resistance & Good to Excellent \\
\hline Sunlight Resistance & Excellent \\
\hline Weather Resistance & Excellent \\
\hline Water Resistance & Excellent \\
\hline
\end{tabular}

The roof of all type of buildings needs commercial waterproofing and residential waterproofing to keep it safe, strong and to last longer. White poly-flex surfaces reflect unwanted summer heat may reduce the heat transmission into the building. The reflectance of a surface is a measure of the energy that is neither absorbed nor transmitted and is expressed as a ratio of the reflected energy to the total incident radiation energy (Agrawal, 1974). 


\section{Methodology}

A Sustainable design method can be used to analyze the impacts of green buildings, including all aspects of design such as materials, energy efficiency, water efficiency, and other building performances. It is very essential to combine and optimized all the aspects of design for making a sustainable house. Based on these principles, a proposed plan including details dimensions has been identified by using Revit architecture shown in Fig.6. Following all details, building information is manually inputted to the EDGE software for efficiency analysis.

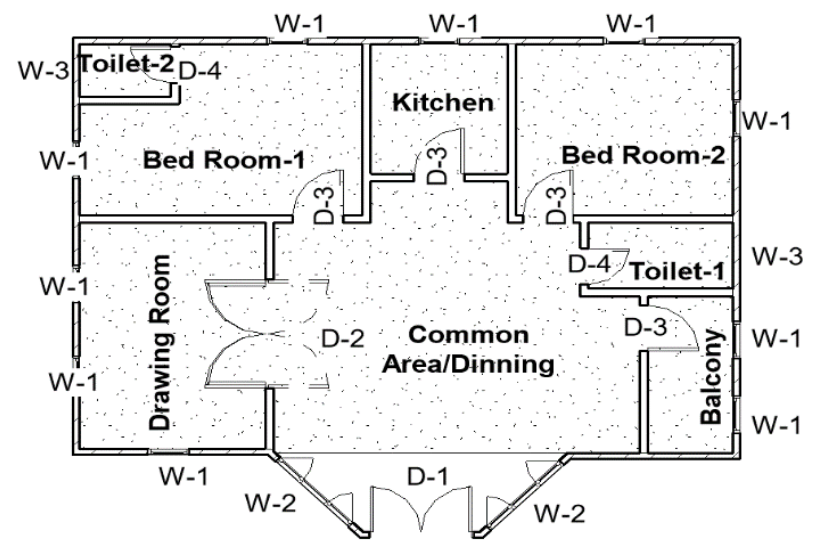

Bed Room 1: $10.8 \mathrm{~m}^{2}$, Bed Room 2:9.5 m², Common Area/Dinning: $26 \mathrm{~m}^{2}$, Drawing Room: $10.7 \mathrm{~m}^{2}$, Kitchen: $4.5 \mathrm{~m}^{2}$, Toilet $1: 2.4 \mathrm{~m}^{2}$, Toilet $2: 1.2 \mathrm{~m}^{2}$, Balcony: $3.4 \mathrm{~m}^{2}$, D1: 60 "X80", D2: 72"X84", D3: 30"X84”, D4: 30"X80”, W1: 24"X42", W2: 61"X48",W3: 18"X24",

Figure 6. Proposed house plan (Area: $75 \mathrm{~m}^{2}$ ) with dimensions (Software: Revit 2019)

By using the EDGE software, a designer can determine the optimal combination of design policies for the superlative return on the venture. Created on a building's parameters, the EDGE software discovers energy- and money-saving design prospects over the region-specific and user-based investigation. As a free design tool, EDGE offerings savings and payback periods, hypothetical costs for green building dealings such as low-flow taps and solar connectors that helping the developers and make the business case for green building (GBCI-2018).

\section{Resources Efficiency}

It is important to improve the energy performance of sustainable buildings which leads to increasing our energy independence. Functioning net-zero energy buildings is one method to expressively decrease our necessity of fossil fuel-derived energy. Following criteria [Table-2] to be considered when designing a sustainable house by using EDGE sustainability analysis.

Reducing water consumption and protecting water quality are key objectives in a sustainable house. Here we considered two options for optimizing the water such as groundwater and rainwater harvesting system technology which is a very simple and low-cost one. Involves the collection of rainwater using either sheet material rooftop and guttering or a plastic sheet, and then diverting the water to a storage tank $[14,15]$.

Choose sustainable construction materials and products by assessing numerous characteristics such as local production, reused and recycled, low toxicity and low off-gassing of harmful air emissions, sustainably harvested materials, high recyclability, durability etc.

Table 2. Several efficiency measures to achieve higher optimization for green building.

\begin{tabular}{|c|c|c|}
\hline Energy efficiency measures & Water efficiency measures & Materials efficiency measures \\
\hline Reduced Window to Wall Ratio - WWR of $10 \%$ & Low-Flow Showerheads - $9 \mathrm{~L} / \mathrm{min}$ & $\begin{array}{l}\text { Floor Slabs: Reuse of existing floor slab } \\
\text { 100mm thickness }\end{array}$ \\
\hline $\begin{array}{l}\text { Reflective Paint/Tiles for Roof - Solar } \\
\text { Reflectivity (albedo) of } 0.6\end{array}$ & $\begin{array}{l}\text { Low-Flow Faucets for Kitchen Sinks - } \\
5 \mathrm{~L} / \mathrm{min}\end{array}$ & $\begin{array}{l}\text { Roof Construction: Clay roofing tiles on } \\
\text { timber rafters } 100 \%\end{array}$ \\
\hline $\begin{array}{l}\text { Reflective Paint for External Walls - Solar } \\
\text { Reflectivity (albedo) of } 0.7\end{array}$ & $\begin{array}{l}\text { Low-Flow Faucets in All Bathrooms - } \\
6 \mathrm{~L} / \mathrm{min}\end{array}$ & $\begin{array}{l}\text { External Walls: Fly ash stabilized soil } \\
\text { blocks }\end{array}$ \\
\hline Insulation of Roof: U-value of 0.5 & $\begin{array}{l}\text { Rainwater Harvesting System - } 60 \% \\
\text { of Roof Area Used for Rainwater } \\
\text { Collection }\end{array}$ & $\begin{array}{l}\text { Internal Walls: Cement fiber boards on } \\
\text { timber studs }\end{array}$ \\
\hline Insulation of External Walls: U-value of 0.45 & & Flooring: Terracotta tiles \\
\hline Natural Ventilation & & Window Frames: Timber 100\% \\
\hline $\begin{array}{l}\text { Energy-Efficient Refrigerators and Clothes } \\
\text { Washing Machines }\end{array}$ & & Wall Insulation: cork $25 \mathrm{~mm}$ \\
\hline Energy-Saving Light Bulbs - Internal Spaces & & Roof Insulation: Mineral wool $25 \mathrm{~mm}$ \\
\hline \multicolumn{3}{|l|}{$\begin{array}{l}\text { Energy-Saving Light Bulbs - Common Areas and } \\
\text { Outdoor Areas }\end{array}$} \\
\hline \multicolumn{3}{|l|}{$\begin{array}{l}\text { Solar Hot Water Collectors - } 50 \% \text { of Hot Water } \\
\text { Demand }\end{array}$} \\
\hline $\begin{array}{l}\text { Solar Photovoltaics - } 25 \% \text { of Total Energy } \\
\text { Demand }\end{array}$ & & \\
\hline
\end{tabular}




\section{Result and Discussion}

To make a green building that can not only minimize the influence on the environment, but also remain economical, practical, and comfortable for use. It is vital to explore integrated green building design, in which the design team works together throughout the entire process, as well as deliberate each aspect of a building in an integrative and rounded manner.

Considering two design concepts such as non-conventional and conventional, design team tries to optimize materials, energy, water, embodied the energy and carbon content and indoor environmental quality. Based on the previous assumption enlisted at Table-2, there are about $59.32 \%$ energy will be saved for a proposed green building as compared to the conventional building shown in Fig.7.

From Fig. 8 it has clearly observed that nearby $44.81 \%$ water will be saved when we will be considered water efficiencies measures such as rainwater harvesting, low-flow faucets for kitchen sinks and bathrooms. The overall efficiency outcomes from EDGE cloud service has been described in Table-3:

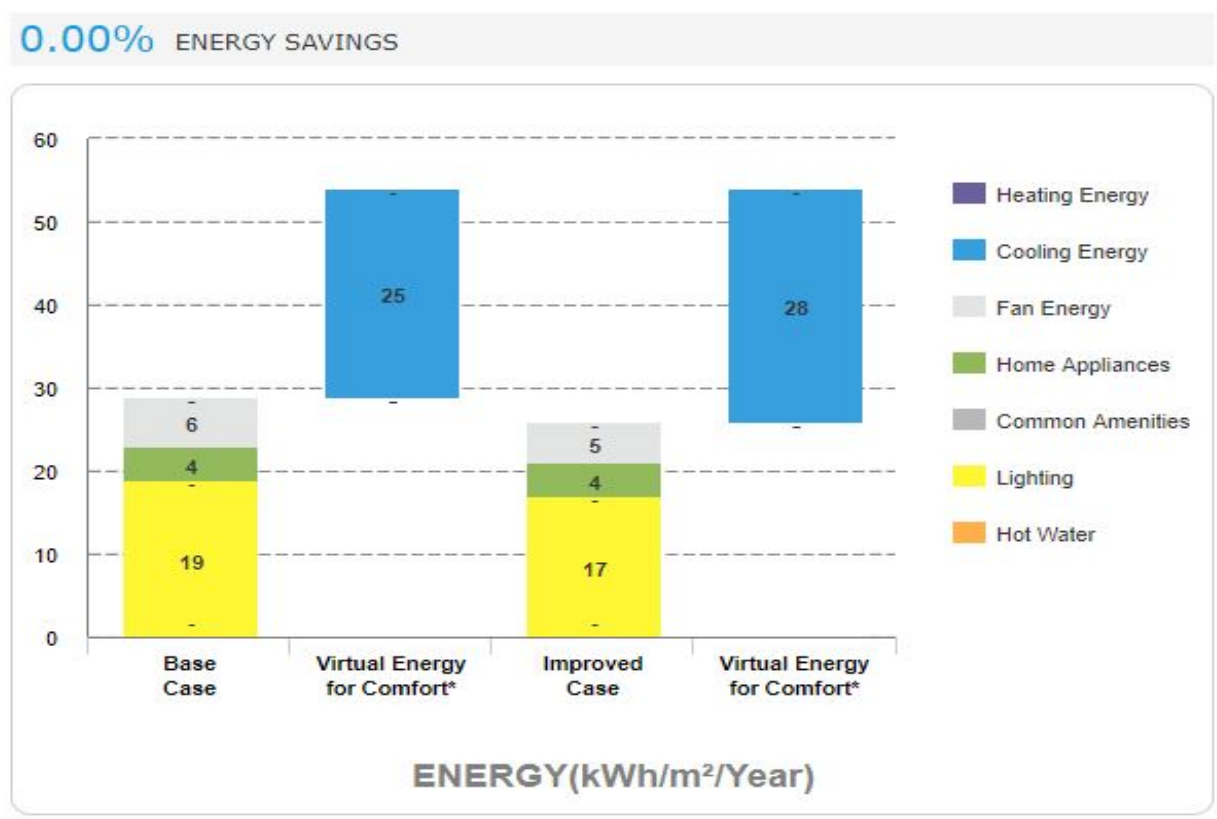

\section{$59.32 \%$ Meets EDGE Energy Standard}

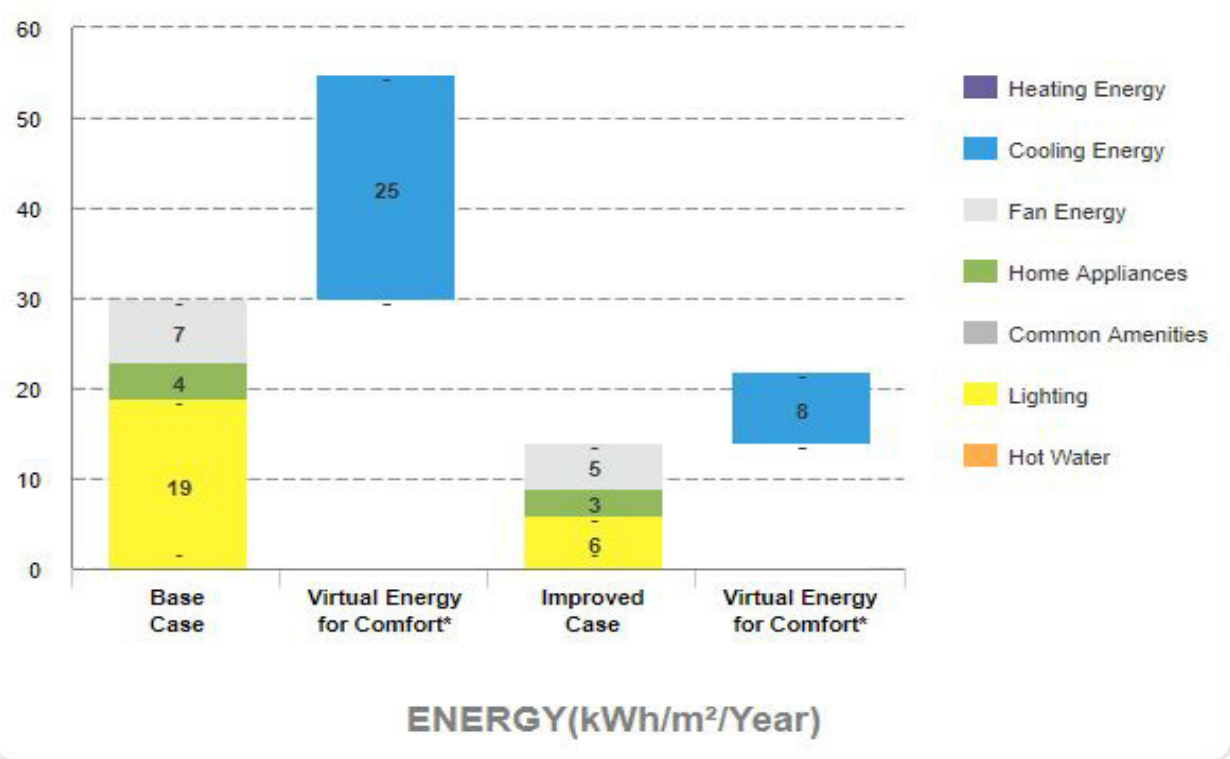

Figure 7. Energy savings for the proposed house according to EDGE energy standard 


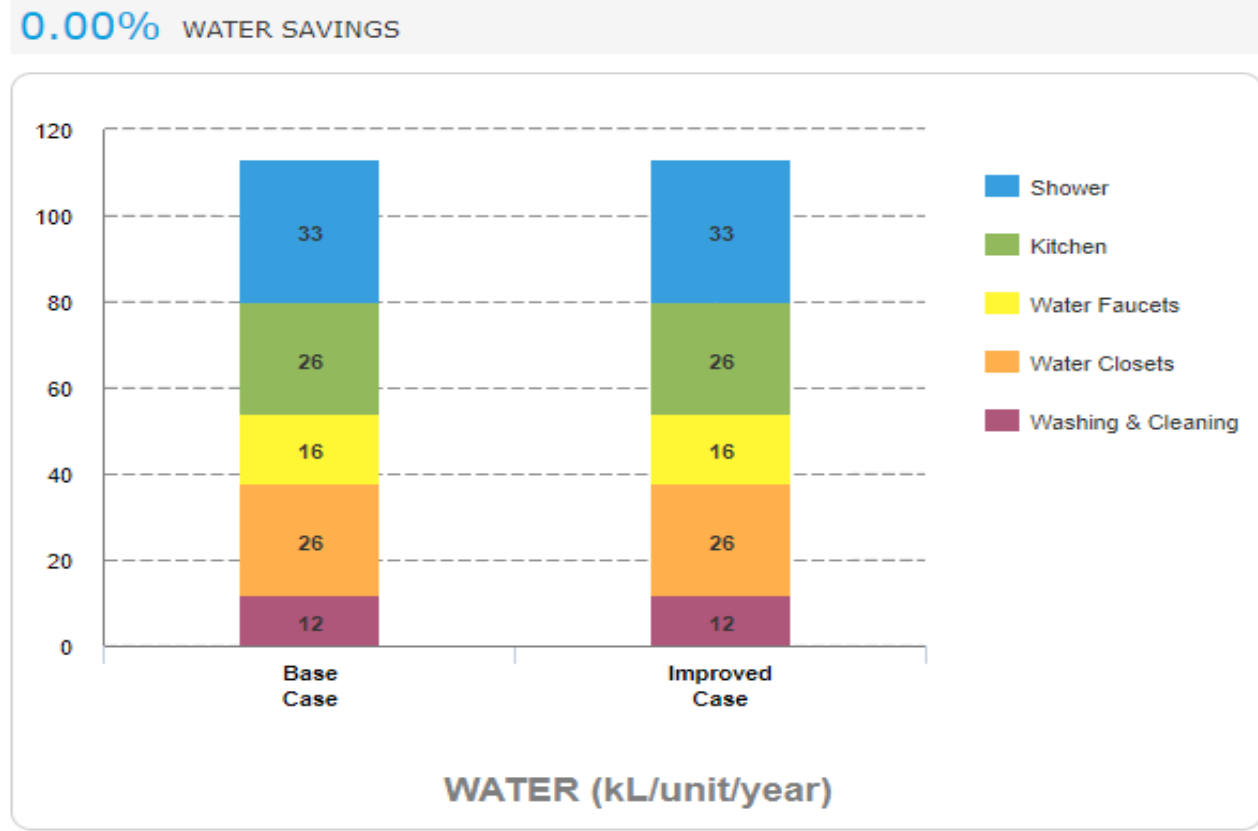

\subsection{1\% Meets EDGE Water Standard}

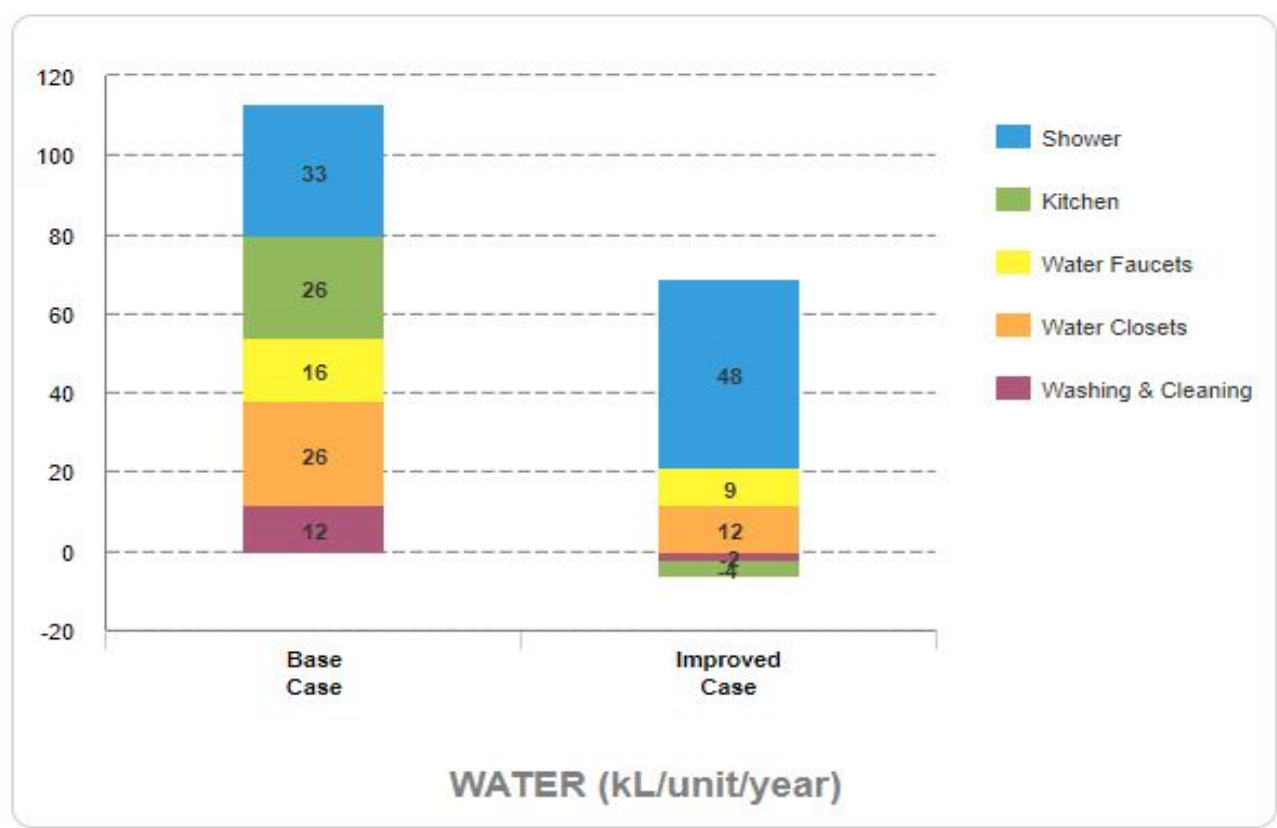

Figure 8. Water savings for a proposed house according to EDGE water standard

Table 3. Overall outcomes for proposed Building

\begin{tabular}{|l|l|}
\hline Particulars/Descriptions & Results/Outcome \\
\hline Final Energy Use & $79.84 \mathrm{kWh} /$ Month/Unit \\
\hline Energy Savings & $22.33 \mathrm{MWh} /$ Year \\
\hline Final Water Use & $5.22 \mathrm{~kL} /$ Month/Unit \\
\hline Water Savings & $356.14\left(\mathrm{~m}^{3} /\right.$ Year $)$ \\
\hline Operational $\mathrm{CO}_{2}$ Savings & $0.74 \mathrm{tCO}_{2} /$ Year/ \\
\hline Embodied Energy Savings & $238826.94 \mathrm{MJ} /$ Unit \\
\hline
\end{tabular}


From embodied energy analysis statistics [Fig.9], it has shown that more than $90 \%$ efficiency standard meets with the EDGE criteria when we considered sustainable and locally available materials for the floor, roof, external wall, internal wall, flooring, windows, and insulation.

Additionally, by considering two design concepts such as non-conventional [Table-4] and conventional [Table-5], design team try to calculate embodied energy \& carbon content for selected locally available materials by using ICE database [16]. The number of materials was calculated by using online materials calculation tools [17] as well as the locally available technique at Pondicherry, India.

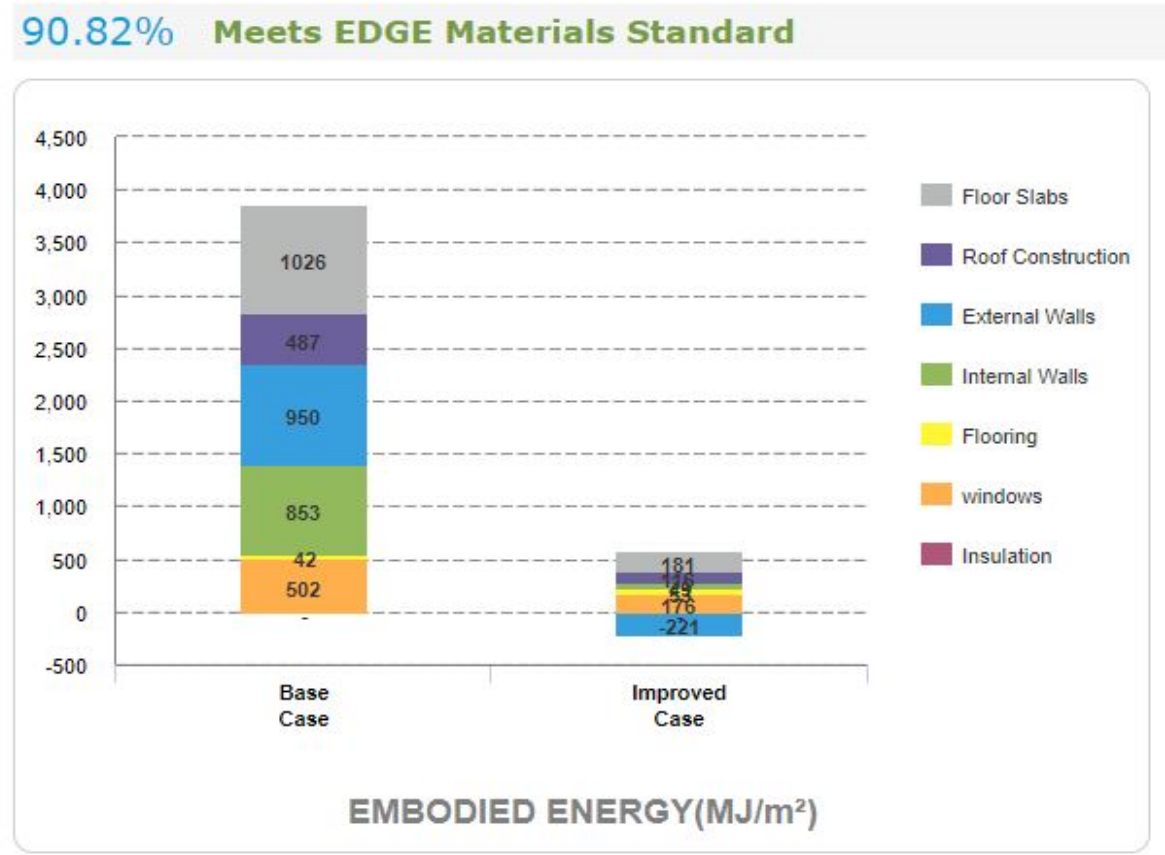

Figure 9. Materials proficiency measurement for the proposed house

Table 4. Embodied Energy \& Carbon content for non-conventional Design (Carbon $\mathrm{kgCO}_{2} /$ Unit \& Embodied Energy (MJ)/Unit

\begin{tabular}{|c|c|c|c|c|c|c|c|}
\hline No & Item Description & Quantity & Unit & $\begin{array}{c}\text { Embodied } \\
\text { Carbon } \\
\mathrm{kgCO}_{2} / \text { Unit }\end{array}$ & $\begin{array}{c}\text { Embodied } \\
\text { Carbon } \\
\mathrm{kgCO}_{2} \\
\end{array}$ & $\begin{array}{c}\text { Embodied } \\
\text { Energy(MJ)/ } \\
\text { Unit } \\
\end{array}$ & $\begin{array}{l}\text { Embodied } \\
\text { Energy(MJ) }\end{array}$ \\
\hline 1 & $\begin{array}{l}\text { Stone for foundation } \\
\text { (Limestone) }\end{array}$ & 43.36 & CFT & 0.68 & 29.4848 & 12 & 520.32 \\
\hline 2 & sand & 343.41 & CFT & 0.2 & 68.682 & 4 & 1373.64 \\
\hline 3 & Aggregate (General) & 154.1 & CFT & 0.2 & 30.82 & 4 & 616.4 \\
\hline 4 & Aggregate (General) & 541.68 & CFT & 0.2 & 108.336 & 4 & 2166.72 \\
\hline 5 & Cement (Portland) & 3550 & $\mathrm{Kg}$ & 0.83 & 2946.5 & 4.6 & 16330 \\
\hline 6 & Fly ash bricks & 61150 & $\mathrm{Kg}$ & 0.1 & 6115 & 1.5 & 91725 \\
\hline 7 & window (Timber framed) & 194 & Sqft & 1.4 & 271.6 & 23.1 & 4481.4 \\
\hline 8 & Door (Timber Framed) & 246.4 & Sqft & 1.4 & 344.96 & 23.1 & 5691.84 \\
\hline 9 & column (Timber) & 27.5 & $\mathrm{Cft}$ & 0.005 & 0.1375 & 20.9 & 574.75 \\
\hline 10 & Main Beam (Timber) & 88 & $\mathrm{Cft}$ & 0.005 & 0.44 & 20.9 & 1839.2 \\
\hline 11 & Ceiling (ply Wood) & 1044 & $\mathrm{Kg}$ & 0.81 & 845.64 & 15 & 15660 \\
\hline 12 & Excavation (Septic Tank) & 4134.4 & $\mathrm{Kg}$ & 0.16 & 661.504 & 1.11 & 4589.184 \\
\hline 13 & Steel (Septic Tank) & 83.66 & $\mathrm{Kg}$ & 1.77 & 148.0782 & 24.4 & 2041.304 \\
\hline 14 & $\begin{array}{c}\text { Terrazzo Tiles (floor } 1.5 \mathrm{ft} \\
\text { by } 1.5 \mathrm{ft} \text { ) }\end{array}$ & 1292 & $\mathrm{Kg}$ & 0.12 & 155.04 & 1.4 & 1808.8 \\
\hline 15 & $\begin{array}{c}\text { Tiles (Toilet } 1 \mathrm{ft} \text { by } 1 \mathrm{ft} \text {, Wall } \\
\text { floor) }\end{array}$ & 542.53 & $\mathrm{~kg}$. & 0.12 & 65.1036 & 1.4 & 759.542 \\
\hline 16 & Basin(total-4) & 20 & $\mathrm{Kg}$ & 1.48 & 29.6 & 29 & 580 \\
\hline 17 & Sewer pipe(Domestic) & 55 & $\mathrm{Kg}$ & 2.5 & 137.5 & 67.5 & 3712.5 \\
\hline 18 & Sewer pipe(Septic) & 55 & $\mathrm{Kg}$ & 2.5 & 137.5 & 67.5 & 3712.5 \\
\hline 19 & Combat (2) & 12 & No. & 1.48 & 17.76 & 29 & 348 \\
\hline \multirow[t]{2}{*}{20} & Glass (Window) & 31 & $\mathrm{Kg}$ & 0.85 & 26.35 & 15 & 465 \\
\hline & Total & & & & 12140.04 & & 158996.1 \\
\hline
\end{tabular}


Table 5. Embodied Energy \& Carbon content for Conventional Design (Carbon $\mathrm{kgCO}_{2} /$ Unit \& Embodied Energy (MJ)/Unit

\begin{tabular}{|c|c|c|c|c|c|c|c|}
\hline No & Item Description & Quantity & Unit & $\begin{array}{c}\text { Embodied } \\
\text { Carbon } \\
\mathrm{kgCO}_{2} / \text { Unit } \\
\end{array}$ & $\begin{array}{c}\text { Embodied } \\
\text { Carbon } \\
\mathrm{kgCO}_{2} \\
\end{array}$ & $\begin{array}{c}\text { Embodied } \\
\text { Energy(MJ)/Unit }\end{array}$ & $\begin{array}{c}\text { Embodied } \\
\text { Energy(MJ) }\end{array}$ \\
\hline 1 & $\begin{array}{c}\text { Stone for } \\
\text { foundation(marble) }\end{array}$ & 43.36 & CFT & 2.24 & 97.1264 & 40 & 1734.4 \\
\hline 2 & sand & 343.41 & CFT & 0.2 & 68.682 & 4 & 1373.64 \\
\hline 3 & Aggregate (general) & 154.1 & CFT & 0.2 & 30.82 & 4 & 616.4 \\
\hline 4 & Aggregate (General ) & 541.68 & CFT & 0.2 & 108.336 & 4 & 2166.72 \\
\hline 5 & Cement (Portland) & 3550 & $\mathrm{~kg}$ & 0.83 & 2946.5 & 4.6 & 16330 \\
\hline 6 & Normal bricks & 61150 & $\mathrm{~kg}$ & 0.22 & 13453 & 3 & 183450 \\
\hline 7 & $\begin{array}{l}\text { window (Aluminum } \\
\text { framed) }\end{array}$ & 194 & Sqft & 25.8 & 5005.2 & 506.5 & 98261 \\
\hline 8 & $\begin{array}{l}\text { Door (Aluminum } \\
\text { Framed) }\end{array}$ & 246.4 & Sqft & 28.3 & 6973.12 & 554.2 & 136554.88 \\
\hline 9 & $\begin{array}{l}\text { column (Reinforced } \\
\text { concrete) }\end{array}$ & 7178 & $\mathrm{~kg}$ & 0.018 & 129.204 & 0.26 & 1866.28 \\
\hline 10 & $\begin{array}{c}\text { Main Beam (Reinforced } \\
\text { concrete) }\end{array}$ & 24360 & $\mathrm{~kg}$ & 0.018 & 438.48 & 0.26 & 6333.6 \\
\hline 11 & $\begin{array}{l}\text { Ceiling (Reinforced } \\
\text { concrete) }\end{array}$ & 22739 & $\mathrm{~kg}$ & 0.018 & 409.302 & 0.26 & 5912.14 \\
\hline 12 & Paint & 3234 & sqft & 0.162 & 523.908 & 3.1 & 10025.4 \\
\hline 13 & Primer & 3234 & sqft & 0.081 & 261.954 & 1.55 & 5012.7 \\
\hline 14 & Excavation (Septic Tank) & 4134.4 & $\mathrm{~kg}$ & 0.16 & 661.504 & 1.11 & 4589.184 \\
\hline 15 & Steel (Septic Tank) & 83.66 & $\mathrm{Kg}$ & 1.77 & 148.0782 & 24.4 & 2041.304 \\
\hline 16 & Tiles (floor $1.5 \mathrm{ft}$ by $1.5 \mathrm{ft}$ ) & 1292 & $\mathrm{~kg}$ & 0.59 & 762.28 & 9 & 11628 \\
\hline 17 & $\begin{array}{l}\text { Tiles (Toilet } 1 \mathrm{ft} \text { by } 1 \mathrm{ft} \text {, } \\
\text { wall, and floor) }\end{array}$ & 542.53 & No. & 0.59 & 320.0927 & 9 & 4882.77 \\
\hline 18 & Basin(Total-4) & 20 & $\mathrm{~kg}$ & 1.48 & 29.6 & 29 & 580 \\
\hline 19 & Sewer pipe(Domestic) & 55 & $\mathrm{~kg}$ & 2.5 & 137.5 & 67.5 & 3712.5 \\
\hline 20 & Sewer pipe(Septic) & 55 & $\mathrm{~kg}$ & 2.5 & 137.5 & 67.5 & 3712.5 \\
\hline 21 & Combat (2) & 12 & kg. & 1.48 & 17.76 & 29 & 348 \\
\hline \multirow[t]{2}{*}{22} & Glass (Window) & 31 & $\mathrm{Kg}$ & 0.85 & 26.35 & 15 & 465 \\
\hline & Total & & & & 32686.3 & & 501596.418 \\
\hline
\end{tabular}

By equating two design concepts showing conventional design produced total embodied carbon $32686.3 \mathrm{~kg}$ where the non-conventional design will be produced $12140.04 \mathrm{~kg} \mathrm{CO}_{2}$. Similarly, in the case of embodied energy, the conventional design produced 501596.418 MJ embodied energy where the non-conventional design will be produced 158996.1MJ. So, by selecting the non-conventional design concept amount of reduction of carbon content $62.8 \%$ and amount of reduction of embodied energy $68.3 \%$ illustrate at Table-6. Also, a design status of embodied energy and carbon content for a conventional and non-conventional house are shown in Fig.10.

Table 6. Embodied energy and carbon content for both conventional and non-conventional materials.

\begin{tabular}{|c|c|c|c|c|c|}
\hline \multicolumn{2}{|c|}{ Conventional } & \multicolumn{2}{c|}{ Non- Conventional } & \multicolumn{2}{c|}{ Result/Significance } \\
\hline $\begin{array}{c}\text { Embodied Carbon } \\
\mathrm{kgCO}_{2}\end{array}$ & $\begin{array}{c}\text { Embodied } \\
\text { Energy(MJ) }\end{array}$ & $\begin{array}{c}\text { Embodied Carbon } \\
\mathrm{kgCO}_{2}\end{array}$ & $\begin{array}{c}\text { Embodied } \\
\text { Energy(MJ) }\end{array}$ & $\begin{array}{c}\text { Reduced Carbon } \\
\text { Content (\%) }\end{array}$ & $\begin{array}{c}\text { Reduced } \\
\text { Embodied } \\
\text { Energy }(\%)\end{array}$ \\
\hline $\mathbf{3 2 6 8 6}$ & $\mathbf{5 0 1 5 9 6}$ & $\mathbf{1 2 1 4 0}$ & $\mathbf{1 5 8 9 9 6}$ & $\mathbf{6 2 . 8 \%}$ & $\mathbf{6 8 . 3 \%}$ \\
\hline
\end{tabular}



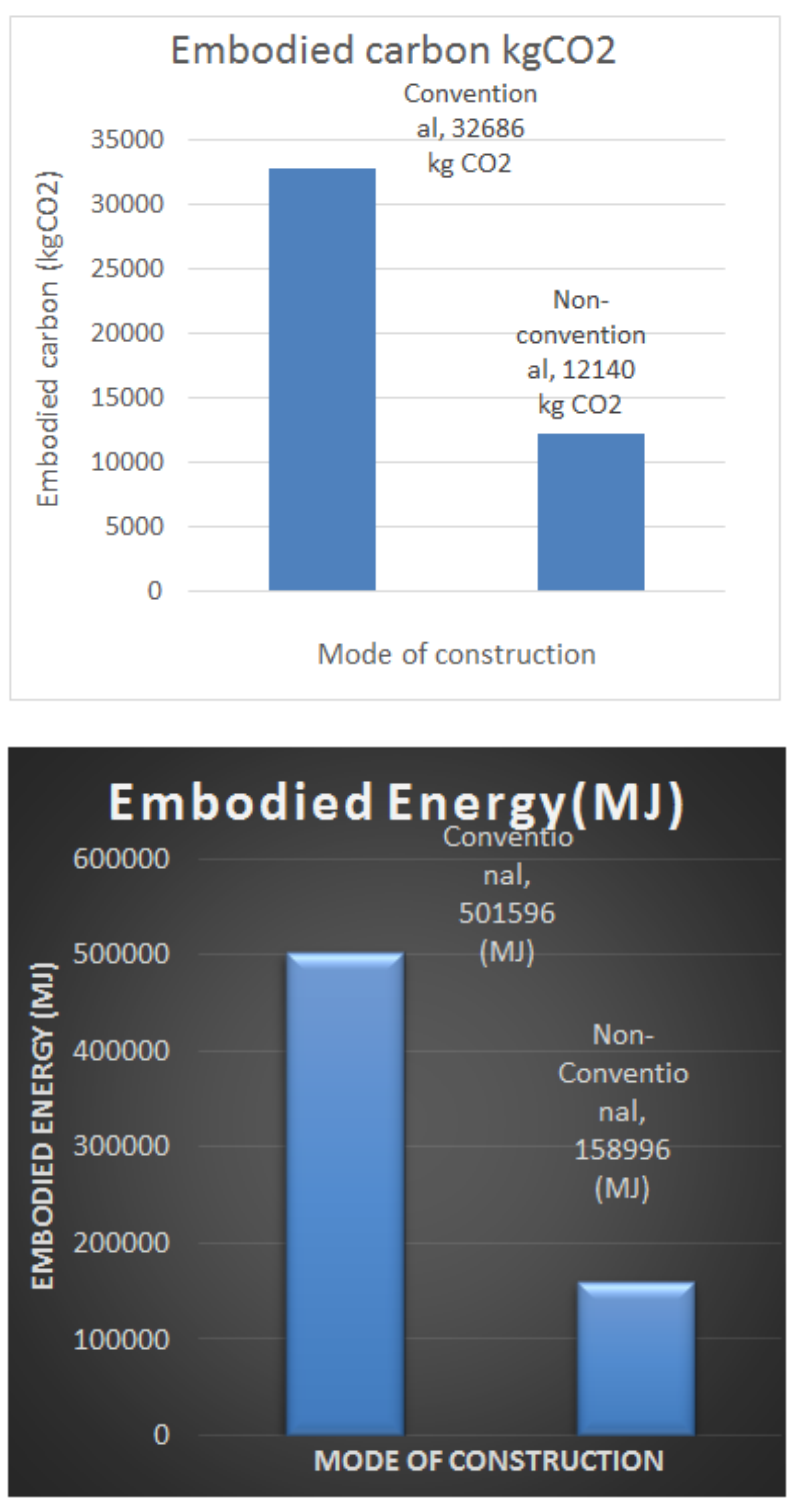

Figure 10. Design status of embodied energy and carbon content for the conventional and non-conventional house.

\section{Cost and Benefits}

Generally, construction costs can be divided into material cost, labor cost and other expenses in the ratio of 60:30:10 respectively [18]. Through studies, it has initiated that the cost of the green building increases by $20 \%$ to $30 \%$ over traditional building techniques. This may be improved from the building operation in term of energy, water, and materials. Price is the most censured issue about creating environmentally friendly buildings at Pondicherry.

From Table-7, It has shown that utility cost, cost reduction, incremental cost and payback periods are 547.09 Rs/Months/Unit, 327.57 Rs/Months/Unit, 222,386.23Rs/Unit and 56.57 years respectively. Design teams suggest making a better analysis in the future to get more efficient results for low-income people at Pondicherry.
Table 7. Cost/Benefits data from EDGE

\begin{tabular}{|l|l|}
\hline Facts /Description & Results \\
\hline Base Case Utility Cost & $547.09 \mathrm{Rs} /$ Month/Unit \\
\hline Utility Cost Reduction & $327.57 \mathrm{Rs} /$ Month/Unit \\
\hline Incremental Cost & $222,386.23 \mathrm{Rs} /$ Unit \\
\hline Payback in Years & 56.57 Years \\
\hline
\end{tabular}

New energy saving appliances, photo-voltaic, and modern technologies lean towards to cost more money [21]. Besides, based on materials listed in Table- 4 and Table-5, an estimated cost of conventional and non-conventional design at Pondicherry has also mentioned in Table-8.

Table 8. Approximate cost of Conventional and Non-Conventional design at Pondicherry

\begin{tabular}{|c|c|c|}
\hline $\begin{array}{c}\text { Cost of } \\
\text { Conventional } \\
\text { Design }\end{array}$ & $\begin{array}{c}\text { Cost of } \\
\text { Non-Conventional } \\
\text { Design }\end{array}$ & $\begin{array}{c}\text { \% Increase } \\
\text { Cost }\end{array}$ \\
\hline Rs. 584913.8 & Rs. 755365.5 & $\mathbf{2 9 \%}$ \\
\hline
\end{tabular}

In terms of use or appearance, there is no difference between conventional and green buildings. The major differences are that green buildings offer operational savings and it has an improved indoor environment [19]. Moreover, the non-conventional house has been observed to have palpable and impalpable benefits [22]. The palpable benefits such as the economic advantages are not immediately visible. However, the lifetime payback is much higher compared with that of conventional buildings, which mainly accumulate from operational cost savings, reduced carbon emission credits and potentially higher rental or capital value $[19,20]$.

\section{Conclusions}

This work is carried out to build on the sustainability issue regarding the optimization of building design at Pondicherry. Optimization in the building sector can be achieved through proper planning. From the study, it can be concluded that this sustainable house in this area is acceptable in terms of energy, water, and materials.

This proposed buildings mainly use the locally available building materials likes terracotta tiles and fly-ash based stabilized blocks. Therefore, it will help to optimize the building materials, embodied energy, construction cost and reducing ecological degradation.

We found that the main factors that influence the green building design in this zone are greener materials as well as plenty of solar radiation. These parameters play an important role in the comfort and endurable analysis of buildings.

It is certainly critical to making the decision to optimize a green building in the early design process for optimizing the green potential, minimize redesign, and assure the overall success and economic feasibility of the building project. Like this, there are some limitation exists which 
are vary locality to locality, region to region \& country to country. This study has got some limitations as particular parts of this research based on field data such as materials information, price, cost, construction data from the local people in this area.

Lastly, we believe this study come up with advanced concept and area to explore the more possibilities and factors for new researchers that influence the sustainable building design in this area as well as other parts of the globe.

\section{Acknowledgements}

This research received no specific grant or funds from any funding agency in the public, commercial, or not-for-profit sectors. The corresponding author would like to acknowledge the South Asia Foundation (http://www.southasiafoundation.org/) for post-graduation fellowship on M.Tech in Green Energy Technology at Pondicherry University in 2013-2015.

\section{REFERENCES}

[1] Zuo, J., \& Zhao, Z. Y. (2014). Green building researchcurrent status and future agenda: A review. Renewable and sustainable energy reviews, 30, 271-281.

[2] Wong, K. D., \& Fan, Q. (2013). Building information modelling (BIM) for sustainable building design. Facilities, 31(3/4), 138-157.

[3] Kibert, C. J. (2016). Sustainable construction: green building design and delivery. John Wiley \& Sons.

[4] Abraham, Pleasa Serin and Gundimeda, Haripriya (2018) "'Greening' the Buildings - An Analysis of Barriers to Adoption in India," Cities and the Environment (CATE): Vol. 10: Iss. 1, Article 10

[5] Dr.Manoj P K (2013) "Prospects and Challenges of Green Buildings and Green Affordable Homes- Concept: A Study with Reference to Ernakulum, Kerala"(Volume:2, Issue:12, ISSN NO 2277-8160.

[6] Puducherry Population Census data 2011. Retrieved November 13, 2018, from http://www.census2011.co.in

[7] Gender Profile Pondicherry. Retrieved November 14, 2018, from http://ncw.nic.in/ and $\mathrm{http} / /$ www.green.aurovilleportal.org/ access on November $15,2018$.

[8] www.earth-auroville.com access on 23rd November 2018.

[9] Darko, E., Nagrath, K., Niaizi, Z., Scott, A., Varsha, D., \& Vijaya, K. (2013). Green building: case study. Shaping policy for Development. Overseas Development Institute, London.

[10] https://digitalfire.com/4sight/glossary/glossary_terra_cotta. $\mathrm{html}$ access on 23rd November 2018.
[11] Chokshi et al. (2014), "A Competitive Assessment on Fly-Ash Bricks and Clay Bricks in Central Gujarat Region of India Using Chi-Square $\operatorname{Test}(\chi 2)$ through SPSS Software". ISSN: 2277-9655.

[12] https://www.apawood.org/plywoodaccess on 21st November 2018.

[13] https://polyglass.us/ access on 25th November 2018.

[14] Dwaikat, L., \& Ali, K. (2016). Measuring the actual energy cost performance of green buildings: A test of the earned value management approach. Energies, 9(3), 188.

[15] M.A. Malek, M.N. Uddin, M. Atiquzzaman, A.H.M.G Hyder, \& S.K. Palit (2014), "Arsenic Contamination of Tube Well Water in Chittagong City- a Case Study". International Journal of Scientific \& Engineering Research, Volume 5, Issue 5, ISSN 2229-5518.

[16] www.carbonsolutions.com access on 25th October 2018.

[17] http://www.hintsandthings.co.uk/, http://www.zhitov.ru/ access on 25th and 29th September 2018.

[18] https://www.cmu.edu/cee/projects/PMbook/05_Cost_Estim ation.html access on 29th October 2018.

[19] Smith, R. M. (2015). "Green" building in India: a comparative and spatial analysis of the LEED-India and GRIHA rating systems. Asian Geographer, 32(2), 73-84.

[20] Yu, S., Tan, Q., Evans, M., Kyle, P., Vu, L., \& Patel, P. L. (2017). Improving building energy efficiency in India: State-level analysis of building energy efficiency policies. Energy Policy, 110, 331-341.

[21] LI, J., \& TIAN, Z. (2011). Incremental Cost-benefit of Life Cycle Green Buildings [J]. Journal of Engineering Management, 5.

[22] Zhang, L., Wu, J., \& Liu, H. (2018). Turning green into gold: A review on the economics of green buildings. Journal of cleaner production, 172, 2234-2245. 